\title{
The Development and Evaluation of Speaking Learning Model by Cooperative Approach
}

\author{
Agus Darmuki \\ Student Sebelas Maret Surakarta State University, Indonesia,
} agus_darmuki@yahoo.co.id

\author{
Andayani \\ Sebelas Maret Surakarta State University, Indonesia,bu_anda09@yahoo.co.id \\ Joko Nurkamto \\ Sebelas Maret Surakarta State University, Indonesia, jokonurkamto@gmail.com \\ Kundharu Saddhono \\ Sebelas Maret Surakarta State University, Indonesia, kundharu@uns.ac.id
}

A cooperative approach-based Speaking Learning Model (SLM) has been developed to improve speaking skill of Higher Education students. This research aimed at evaluating the effectiveness of cooperative-based SLM viewed from the development of student's speaking ability and its effectiveness on speaking activity. This mixed method study combined evaluative descriptive and experimental designs. The population was the first semester students from Department of Indonesian Language and Letter Education, Faculty of Teacher Training and Education in 4 regencies of East Java Province, Indonesia. By stratified random sampling, $50 \%$ of populations were taken as the sample. The research instruments covered questionnaire, interview, FGD, and speaking test. Data reduction, data presentation, and conclusion drawing became the data analyses phases upon questionnaire, interview, and FGD. The data from speaking test were analyzed by t-test in which normality and homogeneity tests were conducted previously. Statistically, both speaking ability scores were different because Fcalculation was 11.380 while Ftable was 3.91 at the significance level $=$ 0.05. Since Fcalculation $>$ Ftable, it can be concluded that cooperative approach gave significant influence in improving speaking ability and was more effective than the conventional one.

Keywords: development, learning model, evaluation, speaking, cooperative approach

Citation: Darmuki, A., Andayani, Nurkamto, J., \& Saddhono, K. (2018). The Development and Evaluation of Speaking Learning Model by Cooperative Approach. International Journal of Instruction, 11(2), 115-128. https://doi.org/10.12973/iji.2018.1129a 


\section{INTRODUCTION}

Speaking activity becomes so essential that many speakers want to know some tricks and theories to have successful and influential speaking to the audience (Bahrani \& Rahmatulloh, 2008; Pan, 2010). Speaking skill is positioned in the first rank of education field (Thornbury, 2005:1). The lecturer's activities from the beginning to the end of the class involve speaking activity (Andayani, 2014); Ridho dkk., 2013: 87-88). Speaking skill must be acquired by both lecturers and students. For students who are learning at Faculty of Teacher Training and Education, speaking skill becomes the main component because they are teacher candidates who will use speaking activity for teaching and learning process.

The facts of teaching and learning process show that there has not been a classroom situation which supports students to speak optimally yet. In terms of lecturers, their teaching and learning have not fully improved the students' interest and potentials on speaking skill yet. The lecturers have not aroused the students' awareness on the importance of speaking. They tend to dominate the teaching and learning process so that the students become passive. The students' achievement, overall, is below the expectation of university curriculum.

The efforts for improving the students' achievement cannot be separated from some influential factors. In this case, lecturers must be more creative in creating the learning process of speaking to be more interesting and favoured by students. According to the Competence-based Curriculum, the learning process demands active students' participation and student-centered learning. The lecturer functions as a motivator and facilitator to enliven the classroom situation. Therefore, a lecturer needs to well plan and build the classroom situation in a certain way using appropriate learning model which gives students great opportunity to interact from one to another. Consequently, personal skill or attitude (affective aspect) and social skill can be reached together with academic achievement (cognitive aspect).

Building educated and smart community in three aspects required paradigm and learning system changes. By a new paradigm, learning practice will move to the one which relies on the constructivism theory. Learning will focus on the development of intellectual ability in social and cultural contexts which begin from the knowledge background and cultural perspective. The learning tasks will be designed to be more interesting and challenging to reach high level of thinking (Aunurrahman, 2010:2).

Based on constructivist theory, during the learning process including the learning of speaking skill, the development of students must be carried out holistically and integrated. Unbalance potential development will lead to one aspect only or partial development. In fact, the growth and development of students belong to the actual goal of all educational institutions and their parties. In essence, a lecturer is not only responsible for material explanation (Hossain \& Tarmizi, 2013), but also holds a strategic role in developing students holistically in terms of cognitive, affective, and psychomotor aspects so that they have personal character (Adebayo \& Judith, 2014). Having knowledge on the course being taught is not sufficient for a lecturer, but she/he 
must holistically consider learning aspects to support students' potentials. Therefore, a lecturer serves for both knowledge transfer and social application.

A lecturer must have comprehensive insights and framework of learning. Learning must be a part of students' learning process which optimizes the students' liveliness and creativity. The existence of constructivist paradigm becomes an alternative which needs to be learnt carefully so that the basic principles can be implemented in the learning process. The success of a learning process is closely related to the lecturer's ability in developing learning models which orientate to improve the intensity of effective student's involvement during the learning process (Attle \& Baker, 2007; Wood \& Chen, 2010; Gilles \& Boyle, 2010; Cheong, 2010; Kupczynski et. al, 2012; Thuy, 2015). The expected development of learning models refers to the development of models which enables students to learn actively and joyfully so as to reach optimal learning outcomes.

Based on the above conditions, the learning process and evaluation of speaking skill are still limited to cognitive aspect and have not touched other aspects as well as character building yet. An educational institution serves not only as a place of knowledge transfer but also as a place for moral enterprise as it belongs to unconscious effort to control human development (Fraenkel, 1977:1-2). The development of students is closely related to responsible changing of behaviour (Marasigan et al, 2014). Students must be responsible for their own thinking. To reach this kind of thinking pattern, the implanting process of character values is required, one of which is through speaking skill. In this context, the characters of appreciating others' opinions and giving opportunity to others (tolerance) are implanted in teaching speaking skill. The curriculum of speaking course is directed to the achievement of behavior, attitude, skill, and knowledge (BASK) (Cholisin \& Hisyam, 2006). Therefore, a lecturer must use a learning model which is interesting and gives opportunity to student to be creative and active during the learning process; as well as to build social knowledge and skill (Gambari \& Yusuf, 2014:1). In short, learning paradigm must be changed from behaviouristic theory which views learning as a mechanical process between stimulus and response, to constructivism theory that argues learning as a social activity to build or create knowledge based on life experience. According to Vygostky (1978), one of constructivism expert, knowledge can be constructed through interaction with others.

By this assumption, a learning model for speaking by cooperative approach is offered. Most research projects have proven that cooperative approach leads to positive attitude toward learning and improves the speaking ability (Hengki, Jabu \& Salija, 2017; Farrell \& Jacobs, 2016; Han, 2015; Alabekee dan Samuel, 2015; Suhendan \& Bengu, 2014; Gambari \& Yusuf, 2014). Cooperative learning can increase the students' activity and creativity, improve interpersonal relationship, and boost learning outcomes due to group cooperation. In other words, Cooperative Learning can penetrate personal, social, and intellectual student's ability.

\section{THEORITICAL REVIEW}

There are three terms related to learning i.e. approach, method, and technique. These three terms are often used for the similar understanding. This research specifically 
discussed about a learning approach. Richards \& Rogers (1986:15) define an approach as a set of correlative assumption dealing with the nature of language teaching and learning. An approach is axiomatic. This research employed a learning approach for speaking in terms of: (1) somebody's insight in viewing speaking skill as learning materials; (2) the content of speaking skill; (3) learning technique and process of speaking skill; (4) plan, implementation, and evaluation in the learning program of speaking skill at Department of Indonesian Language and Letter, Faculty of Teacher Training and Education in Bojonegoro Residency.

Li \& Lam (2013) state that the major theory underlining cooperative learning refers to social constructivism developed by Vygotsky. Jacobsen, Enggen, \& Kauchak (2009:230) argue that cooperative learning is a learning strategy involving students to collaboratively cooperate in reaching the goal. It belongs to a teaching and learning process engaging small groups which enable students to cooperate to maximize somebody's own learning and other's (Jonhson, David W., Jonhson, Roger T., dan Hulubec, Edythe Jonhnson, 2010: 4). The aim of cooperative learning is to create situation in which individual success is determined or influenced by group success (Slavin, 2009:123). It is one of student-centered approaches that has been documented in the existing literature as an effective approach for helping students to acquire meaningful communication skills, practical learning skills, and understanding knowledge skills (Johnson \& Johnson, 2008; Slavin, 2011).

Speaking refers to conveying ideas/thoughts using oral language and media in which humans can communicate from one to another (Flucher, 2003). It is a medium for delivering thoughts, ideas, experience, or information through skills in managing words accompanied by sound, expression, and articulation so as to be understood by the speaking partner. Generally, speaking belongs to the ability in expressing something orally so that someone can be understood by other and vice versa. In this research study, speaking skill is integrated with cooperative learning to improve speaking and social skills.

\section{METHOD}

\section{Research Setting}

This research took place at four private universities namely IKIP PGRI Bojonegoro in Bojonegoro, PGRI Ronggolawe University in Tuban, Darul 'Ulum Islamic University in Lamongan, and STIKIP PGRI Jombang in Jombang.

\section{Research Design}

The researcher used two trial groups as proposed by Fraenkel \& Wallen (1990:237). One group functions as control group and the other serves as experimental group. Both groups were given pre-test. Control group was given treatment using the existing learning model at each campus, while the experimental group was treated using the developed learning model for speaking. At the end of treatment, the results of both groups were compared to know their different learning outcomes. Besides, interview and 
questionnaire were also used to investigate the responses or suggestions from the lecturers and students about the learning model being applied.

\section{Population, Sample, and Sampling}

The research population comprises the first semester students of Department of Indonesian Language and Letter, Faculty of Teacher Training and Education in Bojonegoro, Tuban, Jombang, and Lamongan which have Islamic city background. The sample was the first semester students of four private universities in four regencies. They aged averagely 18 years old. The total lecturers are 18 people who work full-time and have working experience around 5-10 years. The first semester students are groups in class A and class B. The students of class A were used as experimental class, while those of class B served as control group at each university. Each class consists of 40-41 students. IKIP PGRI Bojonegoro as Class A1 (experimental class) and STIKIP PGRI Jombang as Class A2 (experimental class). IKIP PGRI Bojonegoro and STIKIP PGRI Jombang were as Class B1(control class). PGRI Ronggolawe University in Tuban and Darul Ulum Islamic University in Lamongan were as Class B2 (control class). Totally, there were 80 students. The sampling technique employed stratified random sampling based on the class quality at every campus (high, moderate, and low).

\section{Data Collection Techniques}

\section{Questionnaire}

The questionnaire was developed by the researcher using relevant literature to review the cooperative approach-based learning model. Some criteria were used to test the effectiveness of learning model. To gain the validity and to avoid ambiguity, the questionnaire had been checked by experts in language and educational psychology.

\section{Interview}

The information regarding the lecturer's perception toward the effectiveness of cooperative approach-based learning model was collected through interview. Besides, it was also used to get some suggestions on the cooperative based-learning model. This semi-structured interview was in the form of opened-questions about evaluation, effectiveness, and goal of learning required by lecturers. It also contained suggestions for the betterment of cooperative-based learning model.

\section{Speaking Test}

Speaking test was used to know the effectiveness or differences on speaking skill before and after using cooperative approach. The aspects being assessed are pronunciation, intonation, material suitability, expression, and diction. There are 5 scoring classifications i.e. 5 (bad), 10 (good enough), 15 (good), and 20 (very good).

\section{Focus Group Discussion (FGD)}

After having questionnaire, interview, and speaking test to evaluate the implementation of speaking learning model by cooperative approach, FGD was carried out. This activity involved some experts in developing learning models. They are one expert from State 
University of Sebelas Maret Surakarta, 25 lecturers of speaking course, the students as the research samples, and the researcher himself. FGD was intended for determining the strengths and weaknesses of cooperative approach based-learning model in teaching speaking in higher education. The weaknesses are related to the lecturer's preparation, time management, student's character, and class management.

\section{Data Analysis Technique}

The data were analyzed by embedded typed-triangulation of mix-method design (the combination between quantitative and qualitative research methods). This technique was conducted by quantitative and qualitative data analyzed simultaneously as well as combined data (Sugiyono, 2011:46). After that, the analysis results were used to understand the research problems. In this case, the quantitative data provide ways to temporarily generalize the data and give information on the context and place.

Quantitative test was carried out statistically using t-test. The researcher employed statistical program of SPSS to get rapid and accurate data calculation. Descriptivequalitative analyses were implemented on the data regarding validation sheet, observation sheet of implementation phase, cooperative approach-based learning model for speaking skill. Meanwhile, the qualitative data were utilized to describe the student's speaking skill during the learning process. The data triangulation was conducted by analyzing the qualitative and quantitative data simultaneously and then the results were compared. Finally, the interpretation of whether the data are supporting or against each other was also conducted.

\section{FINDINGS}

\section{The Research Results}

The speaking learning model by tolerance-based cooperative approach has been developed based on the needs of lecturers and students in Bojonegoro Ex-Residency. The development can be seen in Table 1 .

Table 1

The Developed Learning Model for Speaking by Cooperative Approach.

\begin{tabular}{llll}
\hline No & Phase & Lecturer's Activity & Student's Activity \\
\hline 1 & $\begin{array}{l}\text { Phase : } 1 \\
\text { Explaining the } \\
\text { learning objectives } \\
\text { and motivating the } \\
\text { students. }\end{array}$ & $\begin{array}{l}\text { The lecturer explains the } \\
\text { learning objectives wanted to } \\
\text { be achieved and motivates the } \\
\text { students to learn. }\end{array}$ & $\begin{array}{l}\text { The students pay attention to the learning } \\
\text { objectives and respond the motivation from } \\
\text { lecturer. (The character values: appreciating } \\
\text { and giving opportunity to others to speak } \\
\text { (listening tolerance)). }\end{array}$ \\
\hline $\begin{array}{ll}\text { Phase : } 2 \\
\text { Presenting } \\
\text { information and } \\
\text { question-answering. }\end{array}$ & $\begin{array}{l}\text { The lecturer conveys } \\
\text { information related to the } \\
\text { learning model and gives }\end{array}$ & $\begin{array}{l}\text { The students listen to the information and } \\
\text { observe the learning model as well as ask thing } \\
\text { that have not been understood yet. (Character }\end{array}$ \\
$\begin{array}{l}\text { Phase : } 3 \\
\text { Organizing the } \\
\text { students into } \\
\text { groups. }\end{array}$ & $\begin{array}{l}\text { The lecturer organizes the } \\
\text { students into some groups and } \\
\text { gives problems to be discussed. }\end{array}$ & $\begin{array}{l}\text { The students make groups based on the lecturer's } \\
\text { instruction. (Character values: tolerating and } \\
\text { appreciating differences) }\end{array}$ \\
& & $\begin{array}{l}\text { The students in group cooperate in understanding } \\
\text { each own part of material. (Character value: } \\
\text { responsible by prioritizing social tolerance) }\end{array}$ \\
\hline
\end{tabular}




\begin{tabular}{|c|c|c|c|}
\hline 4 & $\begin{array}{l}\text { Phase : } 4 \\
\text { Organizing students } \\
\text { into groups and } \\
\text { giving problems in } \\
\text { different topic. }\end{array}$ & $\begin{array}{l}\text { The lecturer guides each group } \\
\text { to learn when the students are } \\
\text { learning. }\end{array}$ & $\begin{array}{l}\text { The students have group discussion and finish } \\
\text { their own part of problem both individually and } \\
\text { in group. (Character value: being tolerant in } \\
\text { socialization) }\end{array}$ \\
\hline 5 & $\begin{array}{l}\text { Phase : } 5 \\
\text { Guiding each group } \\
\text { to work and learn. }\end{array}$ & $\begin{array}{l}\text { The lecturer and students } \\
\text { conclude the materials. }\end{array}$ & $\begin{array}{l}\text { The students in group make conclusions. } \\
\text { (Character value: being tolerant to complete } \\
\text { each other) }\end{array}$ \\
\hline 6 & $\begin{array}{l}\text { Phase : } 6 \\
\text { Evaluation }\end{array}$ & $\begin{array}{l}\text { The lecturer evaluates the } \\
\text { student's learning outcomes, in } \\
\text { terms of intellectual, personal, } \\
\text { and social abilities. }\end{array}$ & $\begin{array}{l}\text { Each student does exercises and fills the } \\
\text { questionnaire on personal and social abilities. } \\
\text { (Character values: honesty and tolerance in } \\
\text { social living) }\end{array}$ \\
\hline 7 & $\begin{array}{l}\text { Phase : } 7 \\
\text { Giving } \\
\text { appreciation. }\end{array}$ & $\begin{array}{l}\text { The lecturer gives appreciation } \\
\text { to the best student both } \\
\text { individually and in group. }\end{array}$ & $\begin{array}{l}\text { The students receive award both individually and } \\
\text { in group. (Character value: being tolerant for } \\
\text { appreciating the success of others) }\end{array}$ \\
\hline
\end{tabular}

The experimental research was carried out in October 2016-May 2017. It involved 2 lecturers per university; so totally, there were 8 lecturers who involved in experimenting cooperative approach for teaching and learning speaking. Before having experimental research, the researcher categorized IKIP PGRI Bojonegoro as Class A1 (experimental class) and STIKIP PGRI Jombang as Class A2 (experimental class). IKIP PGRI Bojonegoro and STIKIP PGRI Jombang were as Class B1(control class). PGRI Ronggolawe University in Tuban and Darul Ulum Islamic University in Lamongan were as Class B2 (control class).

Normality test in this research consists of 8 sample groups with 45 students per group. Sample group of class A1 has 4 groups and so does class A2. The calculation obtained that the value of Asymp Sig (p-value) is greater than the confidence value $\square$ Thus, the sample groups come from population in normal distribution. The level of normality test result is described in Table 2 .

Table 2

The Result of Normality Test of Students from Class A1

\begin{tabular}{lllll}
\hline No & Group & Value of Asymp Sig (p-value) & Confidence Level & Decision of Test \\
\hline 1 & A1 & 0.124 & 0.05 & Normal Data \\
\hline 2 & A2 & 0.178 & 0.05 & Normal Data \\
\hline 3 & B1 & 0.080 & 0.05 & Normal Data \\
\hline 4 & B2 & 0.247 & 0.05 & Normal Data \\
\hline
\end{tabular}

Notes:

A1 : Experimental Group of Class A1 in Pre-test

A2 : Experimental Group of Class A1 in Post-test

B1 : Control Group of Class B1in Pre-test

B2 : Control Group of Class B1 in Post-test 
Table 3

The Result of Normality test of Students from Class A2

\begin{tabular}{lllll}
\hline No & Group & Value of Asymp Sig (p-value) & Confidence Level & Decision of Test \\
\hline 1 & A1 & 0.193 & 0.05 & Normal Data \\
\hline 2 & A2 & 0.139 & 0.05 & Normal Data \\
\hline 3 & B1 & 0.193 & 0.05 & Normal Data \\
\hline 4 & B2 & 0.290 & 0.05 & Normal Data \\
\hline
\end{tabular}

Notes:

A1 : Experimental Group of Class A2 in Pre-test

A2 : Experimental Group of Class A2 in Post-test

B1 : Control Group of Class B2 in Pre-test

B2 : Control Group of Class B2 in Post-test

\section{The Result of Homogeneity Test}

The result of homogeneity test on population variance can be seen in Table 4 .

Table 4

The Result of Homogeneity Test

\begin{tabular}{llllll}
\hline No & Group & Df & p-value & Confidence Level & Decision of Test \\
\hline 1 & A1 & 160 & 0.409 & 0.05 & Normal Data \\
\hline 2 & A2 & 160 & 0.933 & 0.05 & Normal Data \\
\hline 3 & B1 & 159 & 0.956 & 0.05 & Normal Data \\
\hline 4 & B2 & 159 & 0.842 & 0.05 & Normal Data \\
\hline
\end{tabular}

Notes:

A1 : Experimental Group of Students Class A1

B1 : Control Group of Students Class B1

A2 : Experimental Group of Students Class A2

B2 : Control Group of Students Class B2

The overall result of homogeneity test in Table 4 showed that the value of sig is greater than 0.05 . It can be concluded that the variance of population data is homogeneous. Table 5 shows the description of pre-test and post-test results of Experimental Class A1.

Table 5

Speaking Skill_A1_Experimental Pre-test and Post-test

\begin{tabular}{lllllllll}
\hline & $\mathrm{N}$ & $\mathrm{M}$ & $\mathrm{SD}$ & $\begin{array}{l}\text { Error } \\
\text { Standard }\end{array}$ & & $\begin{array}{l}95 \% \text { confidence interval } \\
\text { for mean }\end{array}$ & Minimum & Maximum \\
\cline { 6 - 8 } & & & & & $\begin{array}{l}\text { Lower } \\
\text { Bound }\end{array}$ & $\begin{array}{l}\text { Upper } \\
\text { Bound }\end{array}$ & & \\
\hline Pre-test & 81 & 13.7531 & 2.23903 & .24878 & 13.2580 & 14.2482 & 9.00 & 18.00 \\
\hline Post-test & 81 & 16.3210 & 2.07260 & .23029 & 15.8627 & 16.7793 & 12.00 & 20.00 \\
\hline Total & 162 & 15.0370 & 2.50686 & .19696 & 14.6481 & 15.4260 & 9.00 & 20.00 \\
\hline
\end{tabular}


Table 6

Speaking Skill_A2_Experimental_Pre-test and Post-test

\begin{tabular}{|c|c|c|c|c|c|c|c|c|}
\hline & \multirow[t]{3}{*}{$\mathrm{N}$} & \multirow[t]{3}{*}{$\mathrm{M}$} & \multirow{3}{*}{ SD } & \multirow{3}{*}{$\begin{array}{l}\text { Error } \\
\text { Standard }\end{array}$} & $95 \%$ & confidence & \multirow[t]{3}{*}{ Minimum } & \multirow[t]{3}{*}{ Maximum } \\
\hline & & & & & \multicolumn{2}{|c|}{ interval for mean } & & \\
\hline & & & & & $\begin{array}{l}\text { Lower } \\
\text { Bound }\end{array}$ & $\begin{array}{l}\text { Upper } \\
\text { Bound }\end{array}$ & & \\
\hline Pre-test & 80 & 16.4500 & 2.92480 & .32700 & 15.7991 & 17.1009 & 12.00 & 22.00 \\
\hline Post-test & 80 & 16.4500 & 2.85734 & 31946 & 18.3516 & 19.6234 & 15.00 & 24.00 \\
\hline Total & 160 & 17.7188 & 3.1506 & 24908 & 17.2268 & 18.2107 & 12.00 & 24.00 \\
\hline
\end{tabular}

Table 7

Speaking Skill_B1_Control_Pre-test and Post-test

\begin{tabular}{|c|c|c|c|c|c|c|c|c|}
\hline \multirow[t]{2}{*}{ 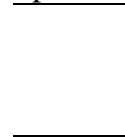 } & \multirow[t]{2}{*}{$\mathrm{N}$} & \multirow[t]{2}{*}{$\mathrm{M}$} & \multirow[t]{2}{*}{ SD } & \multirow[t]{2}{*}{$\begin{array}{l}\text { Std } \\
\text { Error }\end{array}$} & \multicolumn{2}{|c|}{$\begin{array}{l}95 \% \text { confidence } \\
\text { interval for mean }\end{array}$} & \multirow[t]{2}{*}{ Minimum } & \multirow[t]{2}{*}{ Maximum } \\
\hline & & & & & $\begin{array}{l}\text { Lower } \\
\text { Bound }\end{array}$ & $\begin{array}{l}\text { Upper } \\
\text { Bound }\end{array}$ & & \\
\hline Pre-test & 81 & 13.1605 & 2.57612 & .28624 & 12.5909 & 13.7301 & 7.00 & 17.00 \\
\hline Post-test & 81 & 14.7654 & 2.13466 & .23718 & 14.2934 & 15.2374 & 10.00 & 19.00 \\
\hline Total & 162 & 13.9630 & 2.49195 & .19579 & 13.5763 & 14.3496 & 7.00 & 19.00 \\
\hline
\end{tabular}

Table 8

Speaking Skill_B2_Experimental_Pre-test and Post-test

\begin{tabular}{lllllllll} 
& $\mathrm{N}$ & $\mathrm{M}$ & $\mathrm{SD}$ & $\begin{array}{l}\text { Error } \\
\text { Standard }\end{array}$ & & \multicolumn{2}{l}{$\begin{array}{l}95 \% \\
\text { interval for mean }\end{array}$} & \\
\cline { 6 - 8 } & & & & & $\begin{array}{l}\text { Lower } \\
\text { Bound }\end{array}$ & $\begin{array}{l}\text { Upper } \\
\text { Bound }\end{array}$ & & \\
\hline Pre-test & 80 & 15.7250 & 2.90340 & .32461 & 15.0789 & 16.3711 & 10.00 & 20.00 \\
\hline Post-test & 80 & 17.4500 & 2.90743 & .32506 & 16.8030 & 18.0970 & 13.00 & 23.00 \\
\hline Total & 160 & 16.5875 & 3.02274 & .23897 & 16.1155 & 17.0595 & 10.00 & 23.00 \\
\hline
\end{tabular}

Table 9

The result of Questionnaire on Lecturer's Perception

\begin{tabular}{llllll}
\hline No & Item & $\begin{array}{l}\text { Pre-test } \\
\text { Exp (\%) }\end{array}$ & Control (\%) & $\begin{array}{l}\text { Post-test } \\
\text { Exp (\%) }\end{array}$ & Control (\%) \\
\hline 1 & $\begin{array}{l}\text { Learning speaking skill is very } \\
\text { important. }\end{array}$ & 48 & 65 & 100 & 100 \\
\hline 2 & $\begin{array}{l}\text { Teaching speaking skill in the classroom } \\
\text { is easy. }\end{array}$ & 44 & 44 & 82 & 78 \\
\hline 3 & $\begin{array}{l}\text { Speaking skill in the classroom is only } \\
\text { taught by personal instruction. }\end{array}$ & 44 & 27 & 0 & 22 \\
\hline 4 & $\begin{array}{l}\text { The learning process using cooperative } \\
\text { approach is time consuming. }\end{array}$ & 65 & 40 & 0 & 15 \\
\hline 5 & $\begin{array}{l}\text { I want to apply learning model by } \\
\text { cooperative approach. }\end{array}$ & 100 & 100 & 100 & 100 \\
\hline 6 & $\begin{array}{l}\text { I understand the learning process using } \\
\text { cooperative approach. }\end{array}$ & 15 & 40 & 76 & 68 \\
\hline 7 & $\begin{array}{l}\text { I understand evaluating speaking } \\
\text { learning by cooperative approach. }\end{array}$ & 15 & 40 & 83 & 86 \\
\hline & & & & & \\
\hline
\end{tabular}


Table 10

The Result of FGD

The Student's Difficulty The Cause of Student's Difficulty The Lecturer's Strategy in Overcoming Difficulty Lack of bravery to speak Student needs time to exercise Using cooperative approach in teaching speaking in front of the class; shy and rehearse him/herself before for the sake of providing the students opportunity and nervous to speak having public speaking to cooperate and rehearse themselves in small individually groups before performing in front of the class

Low interest in speaking Speaking course is boring and not Directing speaking course to cooperative learning course interesting

Lack of references to Student does not have an example Giving an example of public speaking which is have public speaking and model for public speaking carried out by the lecturer or video show

Too rigid and formal Student needs easygoing and Creating relaxed and unstressful classroom topic unstressful topic situation by giving topics related to situation around the students

The FGD was about the lecturer's problems in teaching speaking. The FGD result showed that (1) the lecturer needs an example/model or learning guidance in teaching speaking; (2) the draft of speaking guidance by cooperative approach is suitable to be applied at Department of Indonesian Language and Letter Education. The things that must be reinforced are (1) giving additional time to train to have public speaking such as homework at the end of each meeting; (2) providing the example of affective assessment.

\section{The Result of Interviewing the Lecturers}

When the lecturers were asked about their preparation before teaching speaking, they said that they just prepared the outline. They had difficulties in arranging lesson plan as the availability of books about speaking was still less. They were difficult in determining the indicator for speaking course. In terms of evaluating speaking skill, particularly for speech, they usually use the aspects of pronunciation, intonation, and facial expression. They have scoring rubric from 6 to 9 but without accompanied by the explanation of descriptors.

\section{The Result of Interviewing the Students}

During the process of interviewing the students, triangulation of data or sources was carried out. Most students from four universities being observed encountered difficulties in public speaking because of some factors. They were not given opportunity to rehearse themselves before performing in front of the class. They lacked of confidence and felt nervous in speaking. The lecturer's topics were too hard and formal which then demotivated them to speak. They need a model/example to have public speaking. In short, all of these factors occurred as a result of lecturer's preparation that was not wellprepared in terms of lesson plan, teaching materials, and assessment indicators/scoring rubrics for speaking skill.

\section{The Result of Observation on Pre-and-Post Cooperative Approach}

Before cooperative approach, the students were passive; only certain students dominated the speaking class. They felt nervous and bored due to the formal topics. After having cooperative approach, most students were active, creative, and cooperated with each other in groups. They felt brave to convey their ideas and thoughts. They were also 
happy because they were shown a video on public speaking. Thus, cooperative learning and its implementation guidance can improve the student's speaking ability and motivate them to be better.

\section{DISCUSSION}

Based on the analysis of statistical data, it was obtained that the average score of student's speaking ability in experimental group during the pre-test was 13.751 and that of post-test was 13.1605. The score of statistical test reported that $F_{\text {calculation }}$ was 2.442 and $F_{\text {table }}$ was 3.91. The significant level 0.05 meant that there were not any differences between experimental and control group before the pre-test as $F_{\text {calculation }}<\mathrm{F}_{\text {table. In }}$ conclusion, the initial condition of student's speaking ability was relatively same between them who were taught by cooperative approach and the ones with conventional method.

To show the effectiveness of learning model, the conditions of pre and post treatment were compared. The students' scores of speaking before treatment were quiet similar. However, after having treatment, the scores of students who taught by cooperative and conventional learning developed.

The statistic test showed that $\mathrm{F}_{\text {calculation }}$ of speaking score in pre-test and post-test obtained 57.062, $F_{\text {table }}$ was 3.91, and the significant level $\square 0.05$, thus $F_{\text {calculation }}<F_{\text {table. }}$ The learning of speaking in higher education can be improved by cooperative approach $(13.7531<16.3210)$. In pre-test and post-test, $F_{\text {calculation }}$ was 8.690 and $F_{\text {table }}$ was 3.91 , the significant level $\square \square 0.05$, thus $\mathrm{F}_{\text {calculation }}<\mathrm{F}_{\text {table. }}$ The average score was $13.1605<$ 14.7654 .

The speaking score of the students taught by cooperative learning is relatively better than the ones taught by conventional learning. The average score of speaking learning by cooperative was 16.3210, higher than that of conventional one by 14.7654 . Statistically this results show differences obtained from the anova test as $\mathrm{F}_{\text {calculation }}$ $22.141, F_{\text {table }} 3.91$, the significant level $\square 0.05$, thus $F_{\text {calculation }}<F_{\text {table. }}$ in short, the cooperative treatment had significant influence on student's speaking ability.

Cooperative learning gave positive impacts on the quality of inter-group relationship, self-esteem, attitude towards academic institution, and the acceptance upon the students with special needs (Hengki, Baso \& Kisman, 2017; Farrell \& Jacobs, 2016; Han, 2015; Alabekee dan Samuel, 2015; Suhendan \& Bengu, 2014; Gambari \& Yusuf, 2014; Slavin, 1995a; Slavin et al, 2003). It can be concluded that cooperative learning is suitable to be implemented in educational institutional with heterogeneous student's background. The significant improvement is indicated by the comparison between the results of pre-test and post-test and the student's speaking performance.

Overall, the results of this research proved that cooperative learning was more effective than the conventional one. (Klimoviene: 2012; Talebi, 2012; Salako dan Adu, 2013; Thuy, 2015; Tran, 2014). Cooperative learning has important elements of consistent monitoring of group interactions, face-to-face interaction, and social skills (Chen \& Goswami, 2011). The success key of cooperative learning in improving the students' 
speaking ability is on the opportunity to empower the student's speaking potential and activate them in the learning process.

\section{CONCLUSION}

The result of this research is very important to teaching and learning speaking. It gave positive influence to the student's success and the effectiveness of learning in the classroom. In conclusion, cooperative learning approach was more effective than the conventional one in improving the speaking ability of students at Department of Indonesian Language and Letter Education. Cooperative approach is proven to be effective in reaching the learning objectives. By cooperative approach, the students get easy in speaking which finally can improve them to speak better. The quality of process and learning outcomes became better. The success of learning is determined by the roles of lecturer, students, and appropriate learning method.

\section{ACKNOWLEDGEMENT}

This research project was supported by a grant from the Ministry of Research Technology and Higher Education, Indonesia.

\section{REFERENCES}

Adebayo, A. S., \& Judith, K. (2014). Comparative study of effectiveness of cooperative learning strategy and traditional instructional method in physics classroom: A case study of Chibote girls secondary school, Kitwe district, Zambia. European Journal of Educational Sciences, 1(1), 30-41.

Alabekee, E. C., \& Samuel, A. (2015). Effect of cooperative learning strategy on students learning experience and achievements in mathematics. International Journal of Education Learning and Development. 3/4, 67-75

Andayani. (2014). Pendekatan Saintifik dan Metodologi Pembelajaran Bahasa Indonesia. Surakarta: Yuma Pustaka.

Attle, S., \& Baker, B. (2007). Cooperative learning a comparative environment: Classroom applications. International Journal and Learning in Higher Education, 19(1), 77-83.

Bahrani, T., \& Soltani, R. (2008). How to teach speaking skill? ELT Journaleltj. Oxford journals. Org, 62(2), 131-138.

Bygate, M. (2000). Speaking. Oxford: Oxford University Press.

Chen, H.Y., \& Goswami, J.S. (2011). Structuring cooperative learning in teaching English pronunciation. English Language Teaching,.4/.3, 26-32. September http://www.ccsenet.org/journal/index.php/elt/article/view/11889.

Cholisin \& Djihad H. (2006). Berorientasi dan pengembangan ilmu pengetahuan sosial di era Indonesia baru. Yogyakarta: Efisiensi Pers. 
Farrell, T. S., \& Jacobs, G. M. (2016). Practicing what we preach: Teacher reflection groups on cooperative learning. TE.SL-EJ, 19(4), 1-9.

Fraenkel, J.R. (1977). How to teach about values: an analytical approach. Englewood, NJ: Prentice Hall.

Fraenkel, J. R., \& Norman E. W. (2009). How to design and evaluate research in education. New York. McGraw-Hill Companies

Fulcher, G. (2003). Testing second language speaking. London: Longman/Pearson Education.

Gambari, I. A., \& Yusuf, M. O. (2014). Effects of three cooperative learning strategies on the performance of secondary school students in Physics. Bulgarian Journal of Science Education, 23(3), 1-23.

Gilles, R., \& Boyle, M. (2010). Teacher reflections on cooperative learning: issues of implementation. Teaching and Teacher Education, 26, 933-940.

Han, M. (2015). An empirical study on the application of cooperative learning to english listening classes. English Language Teaching, 8(3), 177-184.

Hossain, A., \& Tarmizi, R. A. (2013). Effects of cooperative learning on students' achievement and attitudes in secondary mathematics. Procedia-Social and Behavioral Sciences, 93(3), 473-477.

Hengki, H., Jabu, B., \& Salija, K. (2017). The effectiveness of cooperative learning strategy through english village for teaching speaking skill. Journal of Language Teaching and Research, 8(2), 306-312

Johnson, D. W.; Johnson, R. T., \& Holubec, E. J. (2008). Cooperation in the classroom. Edina, MN: Interaction Book Company.

Johnson, D. W., \& Johnson, R. T. (2008). Social interdependence theory and cooperative learning: The teacher's role. New York: Springer. http://dx.doi.org/10.1007/978-0-387-70892-8_1.

Khamkhien, A. (2010). Teaching english speaking and english speaking tests in the thai context: A reflection from Thai perspective. Journal English Language Teaching, 3(1), $20-24$.

Klimoviene, G. (2006). Using cooperative learning to develop language competence and social skill. Studies About Languages, 8, 77-83.

Kupczynski, L., Mundy, MA., Goswami, J., \& Meling, V. (2012). Cooperative learning in distance learning: A mixed methods study. International Journal of Intruction, 2(2), $81-90$

Lavasani, M. G., Afzali, L., \& Afzali, F. (2011). Cooperative learning and social skills. Cypriot Journal of Educational Science, 4(10), 186-193. 
Li, M.P., \& Lam, B.H. (2013). Cooperative learning.The Hong Kong Institute of Education, 1-33.

Marasigan, Arlyne C., \& Allen, A.E. (2014). Modiefied Useful-Learning Approach: ffects on tudents' critical thinking skills and attitude towards chemistry. International Journal of Learning, Teaching and Educational Research, 1(1), 35-72.

Richards, J.C. \& Rogers T.S. (2011). Approaches and methode in language teaching. USA: Cambridge University Press.

Rido, A.; Noraini I. \& Radha M.K.N. (2013). Interaction strategies of master teacher in indonesian vocational classroom: A case study. 3 L Journal of Language Teaching, Linguistics and Literature, 21(3), 85-98.

Salako, E., Eze, I., \& Adu, E. (2013). Effects of cooperative learning on junior secondary school students' knowledge and attitudes to multicultural education concepts in social studies. Education, 133(3), 303-309.

Slavin, R. E. (2009). Cooperative learning teori, riset dan praktik. Bandung: Nusa Media.

Slavin, R.E. (1987). Cooperative learning and the cooperative school. Educational Leadership, 45(2), 7-13.

Slavin, R. E. (2011). Psikologi pendidikan: Teori dan praktik. Jakarta: Indeks.

Sugiyono (2009). Metode penelitian kuantitatif, kualitatif dan $R \& D$. Bandung: Alfabeta.

Sühendan, E. R., \& Bengü, A. A. (2014). The attitudes of students towards cooperative learning in ELT classes. International Online Journal of Education and Teaching, 1(2), 31-45.

Talebi, F., \& Sobhani, A. (2012). The impacts of cooperative learning on oral proficiency. Mediterranean Journal of Social Sciences, 3/3, 75-79.

Thornbury, S. (2005). How to teach speaking. Tanpa Kota: Longman.

Thuy, L. T. B. (2015). An action research on the application of cooperative learning to teaching speaking. TESOL. Journal, 1(2), 332-349.

Tran. V. D. (2014). The effects of cooperative learning on the academic achievement and knowledge retention. International Journal of Higher Education, 3(2), 131-140.

Travis, P. (2011). Overview of spendid speaking website. Studies in Self-Access Learning Journal, 2/1, 39-42.

Vygotsky, L.S. (1978). Mind in society (ed. by M. Cole, V. John-Steiner, S. Scribner, and E. Souberman), Cambridge, MA: Harvard University Press.

Wood, D., \& Chen, K. C. (2010). Evaluating techniques for cooperative learning. International Journal of Management dan Information Systems-First Quarter, 14(1), 51-66. 